\title{
Pengaruh Modal Sosial terhadap Ketahanan Pangan Rumahtangga Petani di Desa Ciaruteun Ilir Kecamatan Cibungbulang Kabupaten Bogor
}

\section{The Impact of Social Capital on Horticultural Farmer Household Food Security in Ciaruteun Ilir Village Cibungbulang sub-district Bogor Regency}

\author{
Sara Endarwati ${ }^{1}$, Ekawati Sri Wahyuni ${ }^{1}$ \\ ${ }^{1}$ Departemen Sains Komunikasi dan Pengembangan Masyarakat, \\ Fakultas Ekologi Manusia, Institut Pertanian Bogor, Bogor.
}

\begin{abstract}
Social capital is an important component in a community. Social capital is used to help each other when in need, such as the need to secure food sufficiency in a household. Social capital consists of trust, networks, and social norms. Household food security is defined as a condition of food suffiency in one household in terms of availability, accesibility and consumability. This study aims to analyze the roles of social capital in household food security in Ciaruteun Ilir village, Cibungbulang subdistrict at Bogor Regency. The data collected by using a survey to 60 horticultural farmer houselds. The farmer's household food security is not determined by socio economic level, spending level and the number of household members. Farmers use the capital social to generate income for buying foods.
\end{abstract}

Keywords: social capital, food security, horticultural farmer

Abstrak

Modal sosial merupakan hal penting yang ada di masyarakat. Modal sosial digunakan untuk saling membantu ketika berada dalam kesulitan, termasuk kesulitan untuk mempertahankan keadaan pangan rumahtangga. Modal sosial terdiri dari kepercayaan, jaringan, dan norma sosial. Ketahanan pangan merupakan keadaan pangan dalam rumahtangga yang tercukupi dari segi ketersediaan pangan, aksesibilitas pangan, dan konsumsi pangan. Penelitian ini bertujuan untuk menganalisis pengaruh pemanfaatan modal sosial terhadap ketahanan rumahtangga di Desa Ciaruteun Ilir Kecamatan Cibungbulang Kabupaten Bogor. Pengumpulan data dilakukan dengan survey terhadap 60 rumahtangga petani sayuran. Ketahanan pangan rumahtangga petani di desa ini tidak dipengaruhi oleh kondisi sosial ekonomi rumahtangga petani yang diukur dari tingkat pendapatan, tingkat pengeluaran, dan jumlah anggota rumahtangga. Rumahtangga petani memanfaatkan modal sosial untuk mendapatkan pekerjaan sehingga dapat membantu menjaga ketahanan pangan rumahtangga.

Kata kunci: modal sosial, ketahanan pangan, petani sayur

\section{Pendahuluan}

Indonesia merupakan negara agraris dengan sektor pertanian sebagai mata pencaharian utama khususnya di pedesaan. Sektor pertanian saat ini tidak lagi menjamin pemenuhan kebutuhan sandang, pangan, dan papan masyarakat di pedesaan. Kebutuhan yang terus meningkat tidak diikuti oleh pendapatan untuk memenuhi ketiga kebutuhan sandang, pangan, dan papan mengakibatkan kemiskinan terus terjadi. Menurut Badan Pusat Statistik (BPS) pada bulan September 2012 terdapat 28,59 juta atau $11,66 \%$ jumlah penduduk miskin di Indonesia. Jumlah penduduk miskin ini lebih banyak terjadi di pedesaan. BPS menyebutkan bahwa jumlah penduduk miskin di pedesaan sampai dengan bulan September 2012 sebanyak 18,08 juta orang atau
$14,70 \%$ sedangkan di perkotaan jumlah penduduk miskin sebanyak 10,51 juta jiwa atau $8,60 \%$. Penduduk miskin di pedesaan tersebut kebanyakan petani gurem dan buruh tani.

Salah satu penyebab terjadinya kemiskinan di pedesaan adalah masalah pangan. Pangan menjadi bahasan pokok untuk menyelesaikan kemiskinan karena terkait dengan pemenuhan kebutuhan pangan. Pangan merupakan hal penting yang harus dipenuhi oleh manusia demi kelangsungan hidupnya. Masalah pangan ini tidak hanya terjadi di Indonesia tetapi juga terjadi di berbagai dunia. Organisasi Pangan Dunia (FAO) belum lama ini melaporkan indeks harga pangan dunia naik pada September 2012 menjadi 215,8 poin dibanding 212,8 poin pada Agustus 2012 (Santosa, 2013). FAO menyatakan bahwa meskipun terjadi kenaikan harga karena kurangnya pasokan, 
namun bukan berarti akan terjadi krisis pangan dalam waktu dekat. Apabila masalah pangan tersebut tidak ditangani dengan baik maka dalam jangka panjang masalah pangan ini dapat menjadi masalah yang berat untuk ditangani.

Pembangunan ketahanan pangan di Indonesia merupakan langkah untuk menyelesaikan masalah pangan. Ketahanan pangan merupakan kondisi ketersediaan pangan yang cukup bagi setiap orang pada setiap saat dan setiap individu memiliki akses untuk memperolehnya baik secara fisik maupun ekonomi (Soetrisno 1998 dalam Mustofa, 2012). Lebih lanjut lagi, Mustofa menjelaskan bahwa fokus ketahanan pangan tidak hanya pada penyediaan pangan tingkat wilayah tetapi juga penyediaan dan konsumsi pangan tingkat daerah dan rumahtangga bahkan individu dalam memenuhi kebutuhan gizinya.

Indonesia berkomitmen untuk mewujudkan ketahanan pangan melalui Undang-Undang Nomor. 7 Tahun 1996 tentang pangan. Menurut UndangUndang Nomor. 7 Tahun 1996, usaha untuk mewujudkan ketahanan pangan merupakan tanggung jawab pemerintah dan masyarakat. Hal tersebut diwujudkan melalui pengaturan, pembinaan, pengendalian, dan pengawasan terhadap ketersediaan pangan yang cukup baik jumlah atau mutunya, aman, bergizi, beragam, merata, dan terjangkau oleh daya beli masyarakat. Santosa (2013) menjelaskan bahwa tantangan untuk menciptakan ketahanan pangan yang mengarah kepada kedaulatan pangan pada masa-masa mendatang akan terasa berat, kalau pangan di Indonesia tidak ditangani secara serius. Kondisi ketahanan pangan dapat dicapai melalui empat komponen, diantaranya kecukupan ketersediaan pangan, stabilitas ketersediaan pangan tanpa fluktuasi, aksesibilitas atau keterjangkauan terhadap pangan, dan kualitas atau keamanan pangan. Ketahanan pangan dapat diciptakan melalui modal sosial, yaitu berupa usaha mandiri dan solidaritas kolektif dalam menghadapi problem kemiskinan dan lemahnya ketahanan pangan yang dihadapi masyarakat (Sinaga dan Rudiyanto, 2012). Lebih lanjut Sinaga dan Rudiyanto (2012) menjelaskan bahwa modal sosial menekankan pada jaringan hubungan sosial (network) yang diikat antara lain oleh kepemilikan informasi, rasa percaya, saling memahami, dan kesamaan nilai serta saling mendukung. Modal sosial juga menekankan pada karakteristik (traits) yang melekat (embedded) pada diri individu yang terlibat dalam interaksi sosial sebagai kemampuan orang untuk bekerja bersama untuk satu tujuan bersama di dalam grup dan organisasi. Kerjasama yang dibangun terkait dengan faktor rasa saling percaya, norma dan Jaringan yang merupakan kunci dari modal sosial yang dilakukan oleh individu (Mustofa, 2012). Lebih lanjut lagi, Mustofa menjelaskan bahwa rasa saling percaya tercermin dari bagaimana satu individu dan lainnya mempunyai sebuah kesepakatan untuk percaya kepada orang lain. Kepercayaan tersebut tidak datang dengan sendirinya namun terdapat faktor norma atau nilai yang eksis di antara individu tersebut untuk bisa saling mempercayai. Faktor yang terkait dengan norma ini bisa saja berasal dari ikatan budaya, agama dan institusi dan sebagainya. Modal sosial dapat meningkatkan kesadaran individu tentang banyaknya peluang yang dapat dikembangkan untuk kepentingan masyarakat (Inayah, 2012).

Pemanfaatan modal sosial dilakukan melalui pemanfaatan kepercayaan, jaringan, dan norma sosial untuk menjaga komponen ketahanan pangan. Melalui kepercayaan, jaringan, dan norma sosial masyarakat pedesaan khususnya petani dapat memanfaatkan hal tersebut untuk pemenuhan kebutuhan pangan. Pemanfaatan modal sosial yang baik dapat mewujudkan ketahanan pangan dengan melihat komponen kecukupan ketersediaan pangan, aksesibilitas atau keterjangkauan terhadap pangan, dan kualitas atau keamanan pangan dalam konsumsi pangan. Ketika pencapaian ketahanan pangan sudah baik dan maksimal maka pemanfaatan modal sosial oleh kaum masyarakat petani secara optimal digunakan semua.

Masalah utama dalam penelitian yaitu: 1) bagaimana pemanfaatan modal sosial rumahtangga dalam hal kepercayaan, jaringan, dan norma sosial di Desa Ciaruteun Ilir Kecamatan Cibungbulang?; 2), bagaimana pengaruh kondisi sosial ekonomi terhadap status ketahanan pangan rumahtangga Desa Ciaruteun Ilir Kecamatan Cibungbulang?; dan 3) bagaimana pengaruh pemanfaatan modal sosial yang ada terhadap ketahanan pangan rumahtangga yang berada di Desa Ciaruteun Ilir Kecamatan Cibungbulang?

Penelitiandiharapkandapatmemberikanmanfaat bagi 3 (tiga) pihak, yaitu akademisi sebagai literatur bagi yang ingin mengkaji lebih jauh mengenai modal sosial dan ketahanan pangan rumahtangga petani, 
pemerintah sebagai rujukan dalam menganalisis pemanfaatan modal sosial dan ketahanan pangan rumahtangga petani untuk membuat kebijakan terkait ketahanan pangan nasional, dan masyarakat khususnya warga Desa Ciaruteun Ilir sebagai bahan penambah pengetahuan mengenai modal sosial dan ketahanan pangan rumahtangga petani.

\section{Metode Penelitian}

Metode yang digunakan dalam penelitian ini adalahmetodepenelitiansurvei.Penelitianmenggunakan sistem pendekatan penelitian kuantitatif yang didukung oleh data kualitatif. Singarimbun (1989) menyatakan bahwa dalam upaya memperkaya data dan lebih memahami fenomena sosial yang diamati, terdapat usaha untuk menambahkan informasi kualitatif pada data kuantitatif. Pendekatan kualitatif dilakukan untuk mendeskripsikan pemanfaatan modal sosial rumahtangga di Desa Ciaruteun Kecamatan Cibungbulang Kabupaten Bogor, dan juga mendeskripsikan kondisi pangan rumahtangga di Desa Ciaruteun Kecamatan Cibungbulang Kabupaten Bogor. Pendekatan kuantitatif dilakukan untuk menganalisis hubungan kondisi sosial ekonomi rumahtangga terhadap status ketahanan pangan, menganalisis hubungan pemanfaatan modal sosial terhadap status ketahanan pangan rumahtangga. Pendekatan penelitian kualitatif dan kualitatif digunakan untuk memperoleh data primer. Penelitian dilakukan di Desa Ciaruteun Ilir Kecamatan Cibungbulang Kabupaten Bogor. Populasi dalam penelitian ini adalah seluruh petani Desa Ciaruteun Ilir Kecamatan Cibungbulang Kabupaten Bogor. Unit analisis penelitian adalah rumahtangga petani Desa Ciaruteun Ilir Kecamatan Cibungbulang Kabupaten Bogor. Rumahtangga petani merupakan petani yang menggunakan lahan pertanian untuk menanam sayur-sayuran. Data yang digunakan dalam penelitian ini dikumpulkan dari sampel yang diambil secara acak.

Data yang digunakan dalam penelitian adalah data primer dan data sekunder. Data sekunder didapatkan dari studi literatur terkait dan pihak-pihak yang berkaitan dengan lokasi penelitian, yaitu profil Desa Ciaruteun Ilir, data demografi Desa Ciaruteun Ilir, dan data dari Badan Pusat Statistika. Data primer diperoleh dari hasil pengambilan data langsung di lapangan melalui kuisioner dan wawancara mendalam kepada rumahtangga petani dan informan. Kuisioner yang diberikan kepada rumahtangga petani terdiri dari 3 (tiga) bagian. Ketiga bagian tersebut adalah modal sosial, kondisi sosial ekonomi rumahtangga berupa tingkat pendapatan, tingkat pengeluaran, dan jumlah anggota rumahtangga, dan status ketahanan pangan rumahtangga. Wawancara mendalam diberikan kepada rumahtangga petani dan informan berdasarkan panduan pertanyaan yang telah disiapkan dan diikuti dengan pemikiran rumahtangga petani yang berhubungan dengan pertanyaan. Wawancara tersebut digunakan untuk mengetahui pemanfaatan modal sosial bagi rumahtangga di Desa Ciaruteun Ilir dan informasiinformasi lain mengenai ketahanan pangan.

Teknik pengolahan dan analisis data yang digunakan pada penelitian ini terbagi ke dalam 3 (tiga) tahap. Pertama, setelah data diambil di lapangan, data tersebut dimasukkan ke dalam buku kode rumahtangga petani sebelum diolah menggunakan SPSS. Buku kode untuk rumahtangga petani dibuat menggunakan Microsoft Exce/2007 dengan memberikan kode-kode terhadap setiap pertanyaan kuesioner yang diberikan kepada rumahtangga petani. Setelah buku kode dibuat, jawaban setiap pertanyaan dari rumahtangga petani dimasukkan ke buku kode tersebut sebelum diolah. Kedua, setelah semua jawaban dari rumahtangga petani dimasukkan ke buku kode rumahtangga petani, data tersebut diperiksa kembali untuk mendapatkan jawaban yang seragam. Jawaban yang terdapat di kuesioner sangat beragam sehingga perlu disamakan agar nantinya mudah diolah lebih lanjut. Tahap ini masih menggunakan microsoft excel2007. Ketiga, pengolahan data menggunakan SPSS 16.0 dengan menggunakan tabulasi silang.

\section{Hasil dan Pembahasan}

\section{Tingkat Pendapatan}

Variasi pekerjaan yang dimiliki oleh petani sayuran di Desa Ciaruteun Ilir menyebabkan kondisi sosial ekonomi setiap rumahtangga berbeda, salah satunya pada tingkat pendapatan. Pendapatan petani didapatkan dari kegiatan yang berupa jenis pekerjaan usahatani dan kegiatan non-usahatani. Kegiatan usahatani berupa pekerjaan rumahtangga petani sebagai petani, kegiatan non usahatani terdiri 


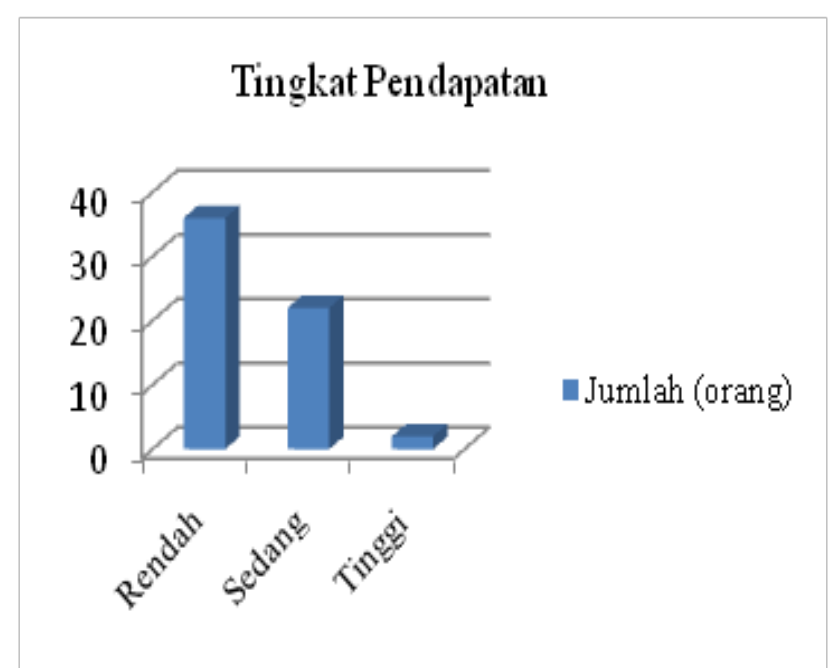

\section{Gambar 1 Tingkat Pendapatan Rumahtangga Petani} Desa Ciaruteun Ilir

dari pekerjaan upah, usaha keluarga, kiriman atau remitan, dan lain-lain. Berdasarkan Gambar 1 dapat diketahui bahwa dari 60 rumahtangga petani sebanyak 36 orang atau 68,33\% rumahtangga petani berada pada tingkat pendapatan ekonomi rendah. Rumahtangga petani yang memiliki tingkat pendapatan rendah disebabkan oleh tidak adanya atau hanya sedikit variasi pekerjaan yang dimiliki oleh anggota rumahtangga apabila dibandingkan dengan rumahtangga lainnya. Mereka mengandalkan pekerjaan sebagai petani untuk mencukupi kebutuhan sehari-harinya. Komoditas sayuran yang ditanam oleh rumahtangga petani ini terdiri dari dua sampai tiga macam saja, yaitu bayam, kangkung, dan kemangi, sehingga tidak ada tambahan pendapatan per bulan. Harga sayuran yang dijual juga mempengaruhi pendapatan yang mereka terima. Rumahtangga petani menjual hasil sayuran yang dipanen ke tengkulak dengan harga yang rendah sehingga pendapatan yang diterimanya juga menurun.

Lahan yang digunakan untuk bertani merupakan lahan orang tua, baik warisan maupun pinjaman untuk dimanfaatkan. Ada beberapa petani yang mendapatkan lahan untuk bertani dari sewa atau kontrak dari bos atau teman mereka. Meskipun pendapatan yang dihasilkan tidak tergolong rendah, petani kadang-kadang mendapatkan bantuan dari pemerintah berupa beras miskin (raskin) dan BLSM. Rumahtangga petani yang memiliki tingkat pendapatan sedang adalah rumahtangga petani yang menanam komoditas sayuran empat sampai lima macam sayuran. Selain bayam, kangkung, dan kemangi, biasanya mereka menanam caesin dan selada sebagai tambahan untuk dijual. Disamping menjadi petani, rumahtangga petani ini biasanya mencari pekerjaan lain sebagai tambahan pendapatan rumahtangganya. Ada yang berkerja masih di bidang pertanian ada juga yang non pertanian. Pekerjaan di bidang pertanian yang dilakukan oleh rumahtangga petani ini adalah kuli sayuran atau pedagang yang menjual sayuran hasil panen mereka.

Pendapatan rumahtangga petani yang tergolong tinggi dihasilkan dari berbagai aktivitas nafkah baik kegiatan usahatani maupun non usahatani. Ada berbagai macam komoditas sayuran yang ditanam dengan hasil yang banyak. Rumahtangga petani ini memiliki lahan yang cukup luas untuk menanam sayuran sehingga hasil yang didapatkan juga banyak. Selain bayam, kangkung, caesin, selada, dan kemangi, mereka juga menanam singkong (diambil daunnya), bunga pepaya.

\section{Tingkat Pengeluaran}

Tingkat pengeluaran rumahtangga petani dibagi menjadi 3 (tiga) bagian, yaitu pengeluaran pangan, non-pangan, dan lainnya. Pengeluaran pangan merupakan kebutuhan sehari-hari yang dibeli atau dibelanjakan oleh rumahtangga petani terkait dengan bahan pangan rumahtangga seperti beras, sayuran, lauk pauk, bumbu dapur, jajan. Pengeluaran non-pangan yaitu pengeluaran selain kebutuhan makanan sehari-hari yang dibelanjakan oleh rumahtangga petani, di antaranya kebutuhan transportasi, pendidikan, pupuk, dan bibit.

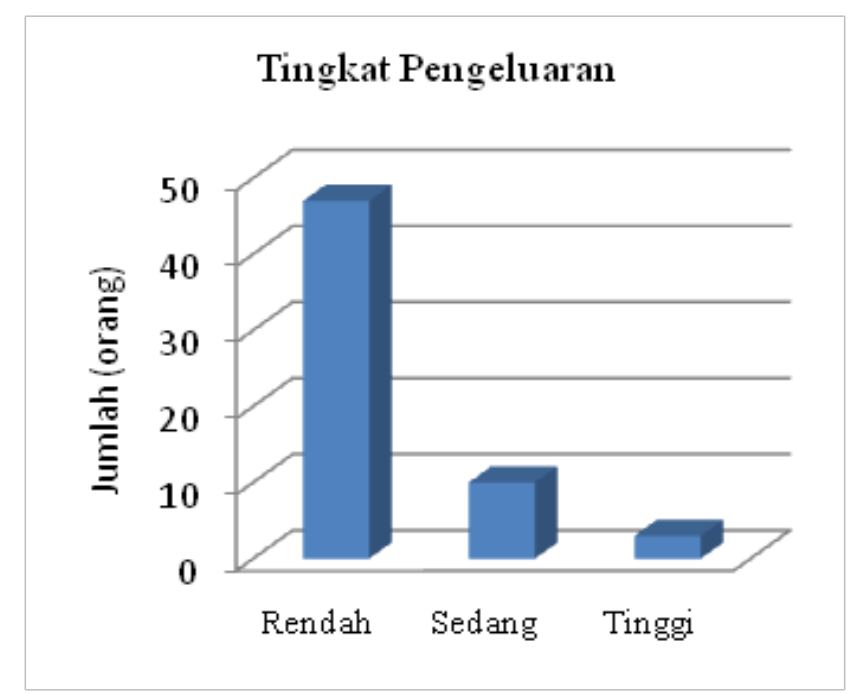

Gambar 2 Tingkat Pengeluaran Rumahtangga Petani Desa Ciaruteun Ilir 


\section{Jumlah Anggota Rumahtangga}

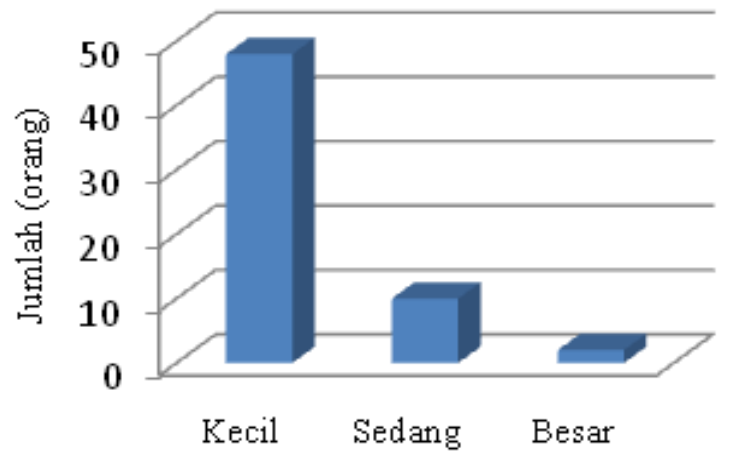

Gambar 3 Jumlah Anggota Rumahtangga Petani Desa Ciaruteun Ilir

Pengeluaran lainnya dalam rumahtangga merupakan pengeluaran selain bahan pangan dan non-pangan seperti arisan, pembayaran hutang. Sebanyak 47 rumahtangga petani berada pada tingkat pengeluaran rendah (Gambar 2). Rumahtangga petani dengan tingkat pengeluaran rendah ini biasanya belanja untuk kebutuhan sehari-hari sesuai dengan pendapatan yang diterimanya. Mereka menyesuaikan makanan, minuman, dan kebutuhan lain dengan pendapatan yang telah diterima setiap hari, minggu, atau bulan. Untuk kebutuhan pangan yang dibeli sehari-hari adalah beras, sayuran, lauk pauk berupa ikan asin, tahu, dan tempe. Kebutuhan pangan tersebut setidaknya yang dibeli oleh rumah tangga petani sehari-harinya.

Kebutuhan non-pangan yang setiap bulan dikeluarkan adalah kebutuhan untuk membeli bahan bakar transportasi yang mereka gunakan. Ada beberapa rumahtangga petani yang memiliki transportasi seperti motor untuk mengangkut hasil panen sayuran mereka ke pasar. Selain kebutuhan bahan bakar, tingkat pengeluaran rumahtangga petani juga dilihat dari angsuran/cicilan kendaraan seperti motor, biaya pendidikan, biaya untuk pupuk dan bibit, biaya arisan dan pinjaman. Arisan dan tabungan masih diperlukan oleh masyarakat untuk tambahan pendapatan meskipun pengeluaran yang dikeluarkantidaksedikit. Denganmengadakan sistem arisan dan tabungan juga membantu masyarakat yang sedang dalam keadaan membutuhkan. Ada satu sistem tabungan masyarakat di Desa Ciaruteun Ilir yang fungsi tabungan tersebut adalah untuk membantu masyarakat yang akan mengadakan hajatan di rumahnya. Biaya yang dikeluarkan oleh setiap rumahtangga seikhlasnya namun wajib untuk membantu yang akan mengadakan hajatan. Biayanya pun beragam sesuai dengan kondisi keuangan masing-masing rumahtangga.

\section{Jumlah Anggota Rumahtangga}

Jumlah anggota rumahtangga adalah jumlah individu yang tinggal atau menetap bersama dalam satu atap dan hidup dalam penghasilan yang sama. Gambar 3 menunjukkan bahwa rumahtangga petani paling banyak berada pada ukuran rendah, yaitu sebanyak 48 orang. jumlah anggota rumahtangga menentukan variasi pekerjaan yang dilakukan oleh anggota rumahtangga. Jumlah anggota rumahtangga yang kecil memiliki variasi pekerjaan yang sedikit sehingga pendapatan yang diterimanya juga rendah. Pekerjaan utama yang dimiliki sebagai petani dirasakan oleh rumahtangga petani sudah mencukupi kebutuhan rumah-tangga karena jumlah anggota rumahtangga yang kecil sehingga tidak memerlukan banyak kebutuhan. Kebutuhan pangan dan nonpangan pada rumahtanggat petani yang tergolong rendah hanya mengandalkan pendapatan kepala rumahtangga atau anggota rumahtangga yang bekerja. Hal ini disebabkan oleh tidak ada tambahan pekerjaan yang dilakukan oleh rumahtangga tersebut sehingga pendapatan yang dihasilkan mengandalkan anggota yang bekerja dan kebutuhan rumahtangga disesuaikan dengan pendapatan yang ada.

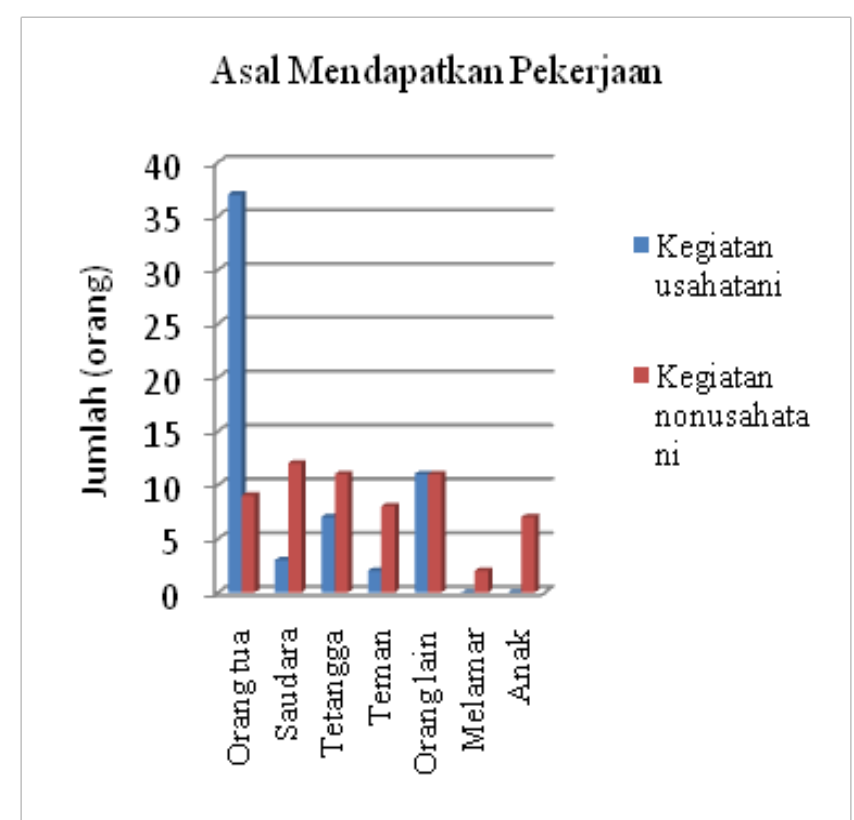

Gambar 4 Asal Mendapatkan Pekerjaan Rumahtangga Petani Desa Ciaruteun Ilir 


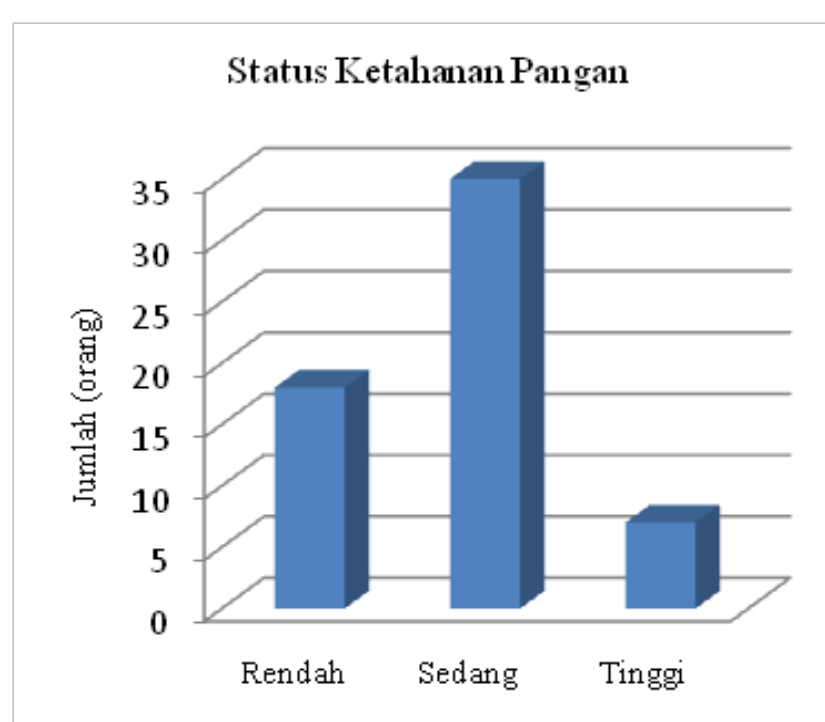

Gambar 5 Status Ketahanan Pangan Rumahtangga Petani Desa Ciaruteun Ilir

\section{Pemanfaatan Modal Sosial Rumahtangga Petani Desa Ciaruteun Ilir}

Pemanfaatan modal sosial merupakan cara-cara rumahtangga memanfaatkan kepercayaan, jaringan, dan norma sosial dalam menjalankan kehidupannya terkait dengan pemenuhan kebutuhan pangan dan non-pangan. Variasi pekerjaan yang dimiliki oleh rumahtangga petani di Desa Ciaruteun Ilir berasal dari berbagai orang yang memberikan pekerjaan. Asal mendapatkan pekerjaan ini berbeda pada kegiatan usahatani dan kegiatan non-usahatani (upah). Kegiatan usahatani merupakan pekerjaan petani yang dilakukan rumahtangga petani seharihari sedangkan kegiatan non usahatani merupakan pekerjaan tambahan anggota rumahtangga untuk menambah pendapatan rumahtangga (Gambar 4).

Pada kegiatan usahatani sebanyak 37 rumahtangga petani mendapatkan pekerjaan usaha tani dari orangtua. Selain orang tua, rumahtangga petani juga dapat memperoleh pekerjaan dalam kegiatan usahatani dari orang lain, tetangga, saudara, dan teman. Bagi rumahtangga petani yang tidak memiliki orang tua, pekerjaan usahatani yang dilakukan mereka dapatkan dari saudara, tetangga, teman, atau orang lain. Orang lain dalam penelitian ini berarti rekan kerja atau pemerintah. Sebanyak 12 orang rumahtangga petani mendapatkan pekerjaannya dari kerabat atau saudaranya pada kegiatan non-usahatani. Pekerjaan non-usahatani ini berupa kuli, buruh, karyawan, pedagang, PNS atau guru, kiriman/remitan, pinjaman dari lembaga/ pemerintah. Tetangga dan orang lain juga menjadi asal rumahtangga petani mendapatkan pekerjaannya. Tetangga biasanya menawarkan pekerjaan yang tidak tetap kepada rumahtangga petani untuk membantu menambah pendapatan rumahtangga.

Asal pekerjaan baik kegiatan usahatani maupun kegiatan nonusahatani berkaitan dengan pemanfaatan modal sosial di Desa Ciaruteun Ilir. Rumahtangga petani di Desa Ciaruteun Ilir masih memanfaatkan modal sosial yang ada di desa dalam mendapatkan pekerjaan. Saat panen sayuran, petani biasanya mendistribusikan hasil panen sayuran tersebut. Distribusi sayuran ini berawal dari petani lalu ke tengkulak dan akhirnya sampai ke pasar. Namun tidak selalu dari petani ke tengkulak terlebih dahulu baru ada di pasar, ada beberapa petani yang langsung menjual hasil panen sayurannya langsung ke pasar. Petani yang langsung menjual hasil panennya ke pasar biasanya dibantu oleh orangtua, kakak atau adik, anak, atau tetangga sekitar rumah. Mereka sudah terbiasa untuk saling membantu ketika masa panen tiba dan terus dilakukan setiap musim panen. Petani yang menjual sayurannya ke tengkulak dipilih oleh tengkulaknya sendiri untuk bergabung. Tengkulak ini mendatangi para petani ke rumah mereka untuk meminte bergabung menjual hasil sayuran yang mereka panen ke tengkulak. Tidak ada kriteria khusus yang diperlukan oleh tengkulak seperti apa petani yang boleh bergabung dengannya. Tengkulak tersebut biasanya tetangga, teman, atau bos dari petani itu sendiri. Satu petani pasti akan memiliki satu tengkulak yang akan menampung sayuran tersebut sehingga tidak terjadi perebutan petani karena semuanya sudah memiliki aturan sendiri. Namun para petani dapat berganti tengkulak ketika mereka merasa sudah tidak ada kesepakatan bersama.

Petani di Desa Ciaruteun Ilir masih memanfaatkan modal sosial yang ada untuk memenuhi kebutuhan rumahtangga petani. Banyak sedikitnya pekerjaan yang dimiliki oleh petani berkaitan dengan kepercayaan yang mereka miliki. Petani yang membutuhkan tenaga kerja untuk mengolah lahan sebelum ditanami sayuran dan saat panen lebih memilih tetangga atau saudara mereka yang sedang menganggur atau sedang tidak melakukan pekerjaannya sehari-hari untuk membantu panen sayuran tersebut. Petani lebih percaya kepada tetangga atau saudara untuk 
Tabel 1 Jumlah dan Persentase Rumahtangga Petani Desa Ciaruteun Ilir menurut Tingkat Pendapatan, Tingkat Pengeluaran Pangan, Tingkat Pengeluaran Nonpangan, Jumlah Anggota Rumahtangga, dan Status Ketahanan Pangan

\begin{tabular}{|c|c|c|c|c|c|c|c|}
\hline \multirow{3}{*}{ Variabel } & \multicolumn{7}{|c|}{ Ketahanan pangan } \\
\hline & \multicolumn{2}{|c|}{ Rendah } & \multicolumn{2}{|c|}{ Sedang } & \multicolumn{2}{|c|}{ Tinggi } & \multirow[b]{2}{*}{$\%$} \\
\hline & & $\mathbf{n}$ & $\%$ & $\mathbf{n}$ & $\%$ & $\mathbf{n}$ & \\
\hline \multirow[t]{3}{*}{ Tingkat pendapatan } & Rendah & 15 & 41,67 & 19 & 52,78 & 2 & 5,55 \\
\hline & Sedang & 3 & 13,63 & 14 & 63,63 & 5 & 22,74 \\
\hline & Tinggi & 0 & 0,00 & 2 & 100,00 & 0 & 0,00 \\
\hline \multirow[t]{3}{*}{ Tingkat pengeluaran pangan } & Rendah & 9 & 24,47 & 21 & 61,76 & 4 & 13,77 \\
\hline & Sedang & 9 & 37,50 & 12 & 50,00 & 3 & 12,50 \\
\hline & Tinggi & 0 & 0,00 & 2 & 100,00 & 0 & 0,00 \\
\hline \multirow[t]{3}{*}{ Tingkat pengeluaran nonpangan } & Rendah & 16 & 33,33 & 27 & 56,25 & 5 & 10,42 \\
\hline & Sedang & 2 & 20,00 & 6 & 60,00 & 2 & 20,00 \\
\hline & Tinggi & 0 & 0,00 & 2 & 100,00 & 7 & 0,00 \\
\hline \multirow[t]{3}{*}{ Jumlah anggota rumahtangga } & Rendah & 12 & 32,43 & 22 & 59,45 & 3 & 8,12 \\
\hline & Sedang & 4 & 22,23 & 10 & 55,54 & 4 & 22,23 \\
\hline & Tinggi & 2 & 40,00 & 3 & 60,00 & 0 & 0,00 \\
\hline
\end{tabular}

melakukan pekerjaan tersebut karena sudah kenal lama dan sering dimintai tolong untuk membantu panen sayuran. Selain itu jarak yang dekat antar rumah juga membuat petani lebih sering meminta tolong ke tetangga atau saudara mereka sendiri.

\section{Status Ketahanan Pangan Rumahtangga Petani Desa Ciaruteun Ilir}

Undang-Undang Nomor. 7 Tahun 1996 menyatakan bahwa ketahanan pangan merupakan kondisi terpenuhinya pangan bagi rumahtangga yang tercermin dari tersedianya pangan yang cukup dalam jumlah maupun mutunya, aman, merata, dan terjangkau. Status ketahanan pangan dilihat dari ketersediaan pangan, akses terhadap pangan, dan konsumsi pangan rumahtangga petani di Desa Ciaruteun Ilir dari konsumsi beras rumahtangga. Status ketahanan pangan rumah tangga petani Desa Ciaruteun Ilir berada pada kelompok yang sedang, yaitu 35 orang (Gambar 5). Status ketahanan pangan sedang menurut tim penelitian ketahanan pangan dan kemiskinan dalam konteks demografi Puslit Kependudukan LIPI (2013) merupakan rumahtangga yang memiiki kontinyuitas pangan/ makanan pokok kontinyu tetapi hanya mempunyai pengeluaran untuk protein nabati saja, kontinuitas dari adanya ketersediaan pangan/makanan kurang kontinyu dan juga mempunyai pengeluaran untuk protein hewani dan nabati. Ketersediaan pangan yang berupa beras, akses terhadap pangan, dan konsumsi pangan rumahtangga petani cukup untuk mempertahankan kondisi pangan mereka sehingga tidak terjadi kelaparan.

Ketersediaan beras di Desa Ciaruteun Ilir dapat dikatakan selalu ada. Pangan yang ada setiap bulannya dapat mencukupi kebutuhan warganya sehingga tidak ada masyarakat yang merasa kekurangan beras untuk makan. Persediaan pangan selain beras pun juga terpenuhi oleh masyarakat khusunya petani. Makanan yang berupa sayuran, lauk pauk, dan bahan nonpangan tersedia di Desa Ciaruteun Ilir. Letak desa yang dekat dengan Pasar Ciampea juga menjadi salah satu faktor persediaan pangan yang cukup untuk masyarakat.

Akses pangan petani Desa Ciaruteun Ilir juga tergolong mudah. Adanya warung di sekitar rumah masyarakat yang menjual kebutuhan pangan memudahkan mereka untuk memenuhi kebutuhan sehari-hari. Setiap RW memiliki sekitar 10 buah warung/toko yang menyediakan bahan pangan bagi masyarakat Desa Ciaruteun Ilir khususnya rumahtangga petani. Selain beras, warung-warung di Desa Ciaruteun Ilir juga menyediakan kebutuhan pangan lain seperti mie, minyak, telur, dan lauk pauk. Pedagang keliling juga ada di Desa Ciaruteun 
Ilir menjajakan dagangannya kepada masyarakat. Selain di warung, beberapa rumahtangga petani juga pergi ke pasar untuk membeli kebutuhan pangan sehari-hari. Masyarakat Desa Ciaruteun Ilir yang memiliki pendapatan yang tinggi biasanya pergi ke pasar. Mereka biasanya pergi ke Pasar Ciampea karena jaraknya yang tidak terlalu jauh dari tempat mereka tinggal dan mudah dijangkau oleh alat transportasi seperti motor dan angkot.

Konsumsi pangan masyarakat Desa Ciaruteun Ilir utamanya adalah beras. Nasi masih menjadi makanan pokokmasyarakatuntuk dikonsumsi. Lahan yang ada di Desa Ciaruteun Ilir dulunya digunakan untuk menanam padi sehingga produksi beras masih tinggi dan pendapatan utama masyarakat berasal dari bertani padi. Namun komoditas yang berubah menjadi sayur-sayuran menjadikan produksi beras semakin lama semakin berkurang. Berkurangnya produksi padi bukan berarti masyarakat tidak lagi mengkonsumsi nasi sebagai makanan pokok mereka. Ada beberapa petani sayuan yang masih menanam padi untuk kebutuhan rumahtangganya sendiri. Petani tidak perlu membeli beras di pasar atau warung karena sudah tercukupi dari pasokan beras hasil menanam sendiri. Selain beras, ada juga ubi dan singkong sebagai tambahan pangan dan atau pengganti beras sebagai pangan pokok. Konsumsi ubi atau singkong ini dilakukan ketika petani atau masyarakat sedang tidak memiliki uang untuk membeli kebutuhan makanan pokoknya. Ubi atau singkong ini tersedia di kebun mereka sehingga mudah dan tidak mengeluarkan biaya ketika akan mengkonsumsinya. Tetangga atau saudara juga biasa memberikan hasil panen singkong atau ubinya sehingga mereka tetap dapat makan meskipun kekurangan biaya.

\section{Pengaruh Kondisi Sosial Ekonomi Terhadap Status Ketahanan Pangan Rumahtangga Petani Desa Ciaruetun Ilir}

Kondisi sosial ekonomi rumahtangga diartikan sebagai keadaan suatu rumahtangga yang diidentifikasi darivariabel tingkatpendapatan, tingkat pengeluaran, dan jumlah anggota rumahtangga. Status ketahanan pangan rumahtangga petani diartikan sebagai keadaan pangan suatu rumahtangga petani yang diidentifikasi dari persediaan pangan, aksesiblitas pangan, dan konsumsi pangan (Tabel 1).
Masing-masing variabel pada kondisi sosial ekonomi memiliki pengaruh yang berbeda terhadap status ketahanan pangan rumahtangga petani. Dari hasil tabulasi silang pada tingkat pendapatan rumahtangga petani, tingkat pendapatan pada rumahtangga petani rendah berada pada status ketahanan pangan sedang, cenderung rendah. Pada petani dengan tingkat pendapatan sedang, sebagian besar pad atingkat ketahanan pangan sedang. Pada tingkat pendapatan tinggi, semua petani termasuk kategori tingkat ketahanan pangan sedang. Kesimpulannya, relatif tidak terdapat kecenderungan hubungan antara tingkat pendapatan dengan status ketahanan pangan. Semua petani dengan tingkat pengeluaran pangan tinggi berada pada status ketahanan pangan sedang. Jadi relatif tidak terdapat kecenderungan pola hubungan antara tingkat pengeluaran pangan dan status ketahan pangan. Pengeluaran pangan dari masing-masing rumahtangga petani masih tercukupi karena pengeluaran rumahtangga yang sesuai dengan kebutuhan sehari-hari. Pengeluaran yang rendah setiap harinya menyebabkan mereka dapat mencukupi kebutuhan pangan mereka dengan memperhitungkan kebutuhan apa saja yang diperlukan untuk kebutuhan sehari-hari.

Pada rumahtangga dengan tingkat pendapatan rendah, ketahanan pangan rumahtangga petani diketahui tetap dalam keadaan baik walaupun pendapatan yang diperoleh tergolong rendah. Ada rumahtangga petani yang tetap dapat makan dan memenuhi kebutuhan pangannya sehari-hari dengan pendapatan yang tergolong rendah. Mereka memanfaatkan lahan yang tersedia ditanami oleh singkong atau ubi untuk membantu kebutuhan pangan. Selain itu, untuk menyiasati pendapatan yang tergolong rendah rumahtangga petani biasanya meminimalkan pengeluaran rumahtangga agar pendapatan tersebut cukup untuk dapat mempertahankan keadaan pangan rumahtangga.

Tingkat pendapatan rumahtangga berasal dari beragam pekerjaan selain pekerjaan utama sebagai petani. Ada banyak cara yang dilakukan untuk mempertahankan keadaan pangan rumahtangga petani. Mereka tidak hanya mengandalkan pekerjaan sebagai sumber pendapatan rumahtangga namun juga ada bantuan dari pihak lain saat mengalami kesulitan pangan. Bantuan dari keluarga, tetangga, atau teman mereka dapatkan untuk saling membantu bagi yang membutuhkan bantuan. Bantuan yang 
diterima oleh rumahtangga petani yang sedang mengalami kesulitan berupa makanan atau uang. Rumahtangga petani satu sering memberikan makanan kepada rumahtangga petani lain saat mereka memiliki lebih banyak makanan. Apabila salah satu rumahtangga petani sedang dalam kesulitan keuangan, biasanya mereka meminjam uang kepada saudara atau kerabat yang memiliki uang lebih yang dapat dipinjamkan. Pinjaman uang ini diperlukan saat rumahtangga petani mengalami kerugian akibat panen sayuran yang mengecewakan. Bantuan-bantuan tersebut ada dengan memanfaatkan modal sosial yang mereka miliki. Pendapatan yang ada tidak selalu membantu rumahtangga petani dalam mempertahankan keadaan pangan mereka namun adanya modal sosial yang masih melekat dan berfungsi dalam masyarakat dapat digunakan sebagai alat penyelamat rumahtangga petani. Petani dengan tingkat pengeluaran pangan rumahtangga petani yang rendah paling banyak berada pada status ketahanan pangan sedang.

Pada tingkat pengeluaran nonpangan, rumah tangga petani dengan tingkat pengeluaran nonpangan rendah memiliki status ketahanan pangan sedang, yaitu sebesar 56,25\%. Pada rumahtangga dengan tingkat pengeluaran tinggi, semua petani termasuk pada status ketahanan pangan sedang. Jadi relatuf tidak terdapat hubungan antara tingkat pengeluaran non pangan dengan status ketahanan pangan. Tingkat pengeluaran non pangan membutuhkan lebih banyak biaya yang digunakan untuk keperluan pertanian seperti bibit, pupuk, dan juga kebutuhan transportasi serta pendidikan sehingga tidak banyak rumahtangga petani yang melakukan pengeluaran nonpangan kecuali untuk bibit dan pupuk karena keduanya merupakan biaya produksi petani.

Petani dengan jumlah anggota rumahtangga yang sedikit, sedang maupun banyak, sebgian besar termasuk dalam status ketahanan pangan sedang. Pada rumahtangga denga jumlah anggota banyak dengan persentase yang lebih besar (40\%) dengan status ketahanan pangan rendah dibandingkan pada rumahtangga dengan jumlah anggota keluarga sedikit dan sedang.

Jumlah anggota rumahtangga petani yang menentukan jumlah orang yang bekerja untuk memenuhi kebutuhan pangan dan non-pangan. Rumahtangga petani yang memiliki jumlah anggota pada kategori sedang maka mereka memiliki variasi pekerjaan yang dilakukan untuk kebutuhan rumahtangganya. Banyaknya jumlah anggota rumah tangga menentukan pekerjaan yang dilakukan namun baik jumlah anggota rumahtangga kecil, sedang, dan besar memiliki usaha sendiri untuk menjaga keadaan pangan rumahtangga. Berdasarkan hasil penelitian, jumlah anggota rumahtangga baik kecil, sedang, ataupun tinggi di Desa Ciaruteun Ilir semuanya berusaha untuk mempertahankan keadaan pangannya agar status ketahanan pangan rumahtangga tetap terjaga.

\section{Pengaruh Pemanfaatan Modal Sosial Terhadap Ketahanan Pangan Rumahtangga Petani Desa Ciaruetun Ilir}

Coleman (1990) menjelaskan bahwa modal sosial didefinisikan sebagai kemampuan masyarakat untuk bekerja sama demi mencapai tujuan bersama di dalam kelompok dan organisasi. Putnam lebih lanjut menjelaskan modal sosial sebagai kepercayaan (trust), jaringan (network), dan norma (norm) yang ada pada masyarakat. Status ketahanan pangan rumahtangga petani diartikan sebagai keadaan pangan suatu rumahtangga petani yang diidentifikasi dari persediaan pangan, aksesibilitas pangan, dan konsumsi pangan.

Kepercayaan sangat dibutuhkan oleh suatu masyarakat dalam berhubungan dengan masyarakat lain. Kepercayaan digunakan oleh para petani untuk mendapatkan pekerjaan untuk dapat mempertahankan ketersediaan cadangan pangan rumahtangga. Banyak masyarakat di Desa Ciaruteun Ilir yang mendapatkan pekerjaan dengan bantuan orang-orang yang ada di lingkungan sekitar, seperti orangtua, saudara, teman, tetangga, atau bahkan orang lain namun yang dekat. Kepercayaan yang diberikan orang lain kepada para petani ini untuk mendapatkan pekerjaan menunjukkan adanya suatu bentuk kepercayaan yang diberikan kepada para petani ini untuk melakukan pekerjaan yang diberikan. Beragam jenis pekerjaan tersebut diberikan kepada para petani dengan alasan jarak rumah mereka yang dekat, hubungan yang dekat, atau memang sudah kenal sejak lama dan merasa kasihan karena kekurangan pekerjaan. Kegiatan usahatani dan juga kegiatan non-usahatani yang dilakukan oleh rumahtangga petani memiliki perbedaan ketika dilihat asal mereka mendapatkan 
pekerjaan.

Kegiatan usahatani yang dimiliki oleh para rumahtangga petani yang berasal dari orangtua memiliki status ketahanan pangan yang sedang. Lahan pertanian yang diberikan oleh orangtua sebagai warisan membuat rumahtangga dapat memenuhi kebutuhan pangannya setiap hari. Rumah tangga ini hanya mengolah lahan yang diberikan oleh orangtua dengan tanpa atau bantuan orang lain. Kepercayaan yang mereka dapatkan dari orangtuanya menyebabkan rumahtangga petani memiliki pekerjaan. Pekerjaan yang dimiliki ini berkaitan erat dengan ketahanan pangan rumahtangga petani. Rumahtangga petani ini dapat mencukupi kebutuhan pangannya tanpa ada yang mengalami kelaparan walaupun ada yang masih merasa kekurangan terhadap kebutuhan pangan rutin mereka. Orangtua memberikan pekerjaan kepada anaknya agar mereka dapat tetap hidup dengan keluarganya. Dengan pekerjaan ini rumahtangga petani mendapatkan pekerjaan warisan dari orangtua mereka.

Orang lain juga menjadi orang yang penting bagi rumahtangga dalam mempertahankan status ketahanan pangannya. orang lain yang dimaksud adalah bos atau pemilik lahan pertanian yang bukan masyarakat asli di Desa Ciaruteun Ilir atau orang Desa Ciaruteun Ilir namun sudah tidak tinggal disana lagi. Rumahtangga petani yang mengenal bos mereka dari berbagai pihak atau orang. Ada beberapa rumahtangga petani yang sudah mengenal lama bos mereka sehingga mereka dipercayai untuk mengolah lahan pertanian yang ada disana. Sebelum diberikan pekerjaan sebagai petani untuk mengolah lahan disana, petani-petani ini dulunya bekerja sebagai anak buah bos dalam pekerjaan yang lain. Dari pekerjaan sebelumnya tersebut mereka diberikan pekerjaan lagi. Hal ini berkaitan dengan kepercayaan yang diberikan bos kepada petani tersebut. Bos petani ini sangat mempercayai petanipetani sehingga berani untuk memberikan pekerjaan lagi walaupun jarak tempat tinggal mereka jauh.

Selain pada kegiatan usahatani, kegiatan non usahatani juga dapat dijelaskan melalui kepercayaan yang diberikan untuk mempertahankan keadaan pangan rumahtangga petani. Saudara memiliki peran yang paling besar bagi rumahtangga petani untuk mendapatkan pekerjaan non-usahatani. Asal mendapatkan pekerjaan non usahatani ini berkaitan dengan status ketahanan pangan rumahtangga petani pada tingkat sedang. Kegiatan non-usahatani ini berupa buruh bangunan, kuli, pegawai, dan lainlain. Untuk mendapatkan pekerjaan di luar pekerjaan petani, anggota rumahtangga petani membutuhkan bantuan orang lain. Bantuan ini paling banyak datang dari saudara mereka. Pada umumnya, petani di Desa Ciaruteun Ilir tinggal berdekatan dengan saudara dan kerabat mereka. Oleh karena itu, untuk meminta bantuan ketika mengalami kesulitan bagi petani di sana tidaklah sulit. Selain pekerjaan petani yang menjadi pekerjaan utama rumahtangga petani, pekerjaan lain mereka perlukan untuk menambah pendapatan rumahtangganya. Pekerjaan di luar usahatani ini memang sangat membantu petani mengingat pekerjaan seorang petani tidak selalu menguntungkan setiap panennya. Terkadang para petani mengalami kerugian akibat hasil panen yang tidak laku karena produksi yang terlalu banyak sehingga mereka membutuhkan tambahan pendapatan.

Rumahtangga petani mendapatkan pekerjaan selain pekerjaan petani atas dasar kepercayaan yang diberikan oleh saudara, teman, tetangga, bahkan sampai orang lain. Saudara atau kerabat sebagai orang terdekat dari keluarga petani memberikan bantuan kepada rumahtangga petani saat mereka mendapatkan kesulitan, termasuk dalam hal pekerjaan. Pekerjaan sebagai kuli misalnya, beberapa rumahtangga petani selain menjadi petani juga menjadi kuli pengangkut sayuran di lahan yang dimiliki oleh saudaranya. Saudaranya meminta tolong beberapa petani untuk melakukan pekerjaan tersebut karena kekurangan tenaga kerja untuk mengangkut sayuran. Selain itu, hubungan saudara dan jarak rumah yang tidak jauh juga menjadi faktor dipilihnya petani yang dekat dengan saudaranya. Saat rumahtangga petani memiliki tambahan pendapatan selain dari menjadi petani maka ketahanan pangan dalam rumahtangganya meningkat. Para petani ini merasa cukup dengan keadaan pangan yang ada saat ini meskipun masih pada keadaan yang sederhana. Pendapatan yang cukup untuk memenuhi kebutuhan sehari-hari menurut mereka itu sudah cukup dan tidak menginginkan tambahan apapun lagi. Semakin banyak pekerjaan yang dimiliki suatu rumahtangga petani maka status ketahanan pangan mereka juga tergolong semakin meningkat.

Jaringan berkaitan dengan hubungan yang dapat dimanfaatkan terkait dengan pekerjaan di Desa 
Ciaruteun Ilir sebagai hasil dari interaksi yang sering dilakukan. Keadaan pangan rumahtangga petani dapat dipertahankan dengan memanfaatkan jaringan yang ada melalui pekerjaan dalam mendistribusikan sayuran hasil panen mereka. Jaringan yang dimiliki oleh rumahtangga petani dalam mendistribusikan hasil pertaniannya sangat diperlukan. Jaringan yang banyak dimiliki oleh petani akan memudahkan mereka menjual sayuran hasil panennya sehingga pendapatan yang dimiliki juga akan meningkat.

Dalam memasarkan hasil panen sayurannya, petani di Desa Ciaruteun Ilir melalui tengkulak atau langsung dijual sendiri ke pasar. Saudara, tetangga, atau teman dari rumahtangga petani menjadi tengkulak sayuran di Desa Ciaruteun Ilir. Hal ini memudahkan petani dalam membuat jaringan dalam memasarkan hasil sayurannya. Petani dapat memilih tengkulak mana yang akan menjual hasil panen sayurannya sehingga keuntungan dan kerugian dapat diperhitung-kan oleh petani. Di Desa Ciaruteun Ilir, petani merasa jaringan yang mereka miliki untuk memasarkan hasil sayurannya saat ini berjalan dengan baik dan tidak terdapat masalah. Dengan adanya jaringan ini pendapatan para petani dapat dikatakan selalu ada walaupun tidak tetap. Walaupun tidak menentu namun hasil dari panen sayuran dapat membantu rumahtangga petani untuk dapat memenuhi kebutuhan pangan rutin mereka. Sebagian masyarakat dapat memperoleh tambahan pendapatan dari hasil kerja non usahatani yang semakin membantu untuk mempertahankan keadaan pangan. Dengan beberapa jaringan yang dimiliki oleh rumahtangga petani dalam mendapatkan pekerjaan baik kegiatan usahatani maupun non usahatani ketahanan pangan rumahtangga petani dalam status sedang. Artinya, berbagai pekerjaan yang dimiliki oleh anggota rumahtangga menyebabkan pendapatan rumahtangga juga beragam dan meningkat sehingga tidak susah bagi rumahtangga petani tersebut untuk memenuhi kebutuhan pangannya.

Norma merupakan segala aturan baik tertulis maupun tidak tertulis yang diterapkan dan dilaksanakan oleh masyarakat. Di Desa Ciaruteun Ilir, terdapat beberapa aturan pada setiap masa panen. Ketika ada petani yang terlebih dahulu panen maka mereka lebih memilih menunggu temanteman petani lain untuk panen bersama sehingga harga yang diberikan untuk sayuran tersebut semuanya sama. Sudah menjadi kebiasaan bersama ketika ada beberapa petani yang mengalami masa panen terlebih dahulu untuk menunggu petani lain yang belum melakukan panen. Hal ini bukanlah kesepakatan bersama sejak awal menjadi petani namun adanya rasa senasib dan sepenanggungan yang menjadikan mereka membuat aturan secara tidak tertulis untuk saling menunggu sampai musim panen tersebut datang bersama-sama.

Tidak hanya pada saat panen, ada beberapa aturan atau norma-norma yang berlaku di masyarakat Desa Ciaruteun Ilir. Desa Ciaruteun Ilir memiliki beberapa kelompok tani, seperti kelompok tani Kunyit dan Tani Jaya. Beberapa masyarakat menjadi anggota kelompok tani tersebut. Adanya kelompok tani ini sangat membantu para petani dalam pertanian. Ketika petani kekurangan modal untuk menanam kembali, kelompok tani menyediakan bantuan berupa dana, bibit, ataupun pupuk untuk melanjutkan penanaman tersebut. Untuk masa pinjaman ini, petani diberikan waktu dengan cicilan yang mereka bisa. Artinya, tidak ada paksaan dari kelompok tani untuk para petani agar dapat membayar hutanghutang tersebut. Namun anggota kelompok tani selalu mencicil hutang-hutang mereka ketika panen datang. Hal tersebut sudah dilakukan petani dengan kesepakatan bersama.

Adanya kelompok tani di Desa Ciaruteun Ilir yang membantu mengatur sistem pertanian di desa tersebut sehingga memudahkan petani untuk mendapatkan bantuan ketika mendapatkan kesulitan. Kelompok tani tersebut juga memiliki aturan sendiri dalam mengatur anggotanya mengelola sistem pertanian mereka. Bantuan yang sering diberikan oleh kelompok tani ini sangat diperlukan oleh petani terutama saat mereka mengalami kekurangan modal untuk tanam sayuran kembali. Saat petani ini tidak memiliki modal lagi untuk tanam kembali kelompok tani memberikan pinjaman untuk tani sekaligus untuk memenuhi kebutuhan pangan petani. Petani sangat terbantu dengan adanya kelompok tani tersebut dan dapat mempertahankan keadaan pangannya pada status sedang.

\section{Kesimpulan}

Pemanfaatan modal sosial yang dilakukan oleh petani di Desa Ciaruteun Ilir adalah dengan menggunakan kepercayaan, jaringan, dan norma sosial untuk mendapatkan pekerjaan baik pekerjaan 
usahatani maupun non usahatani. Modal sosial ini juga digunakan untuk mempertahankan keadaan pangan rumahtangga petani Desa Ciaruteun Ilir. Kepercayaan dan jaringan yang didapatkan dari orangtua, saudara, tetangga, teman, anak, dan lainnya sangat membantu rumahtangga petani untuk dapat menjalani kehidupan sehari-hari sehingga kebutuhan pangan petani dapat terpenuhi.

Kondisi sosial ekonomi rumahtangga petani Desa Ciaruteun Ilir seperti tingkat pendapatan, tingkat pengeluaran, dan jumlah anggota rumah tangga terbukti tidak memiliki pengaruh terhadap status ketahanan pangan rumahtangga petani. Modal sosial memberikan pengaruh kepada status ketahanan pangan petani Desa Ciaruteun Ilir. Modal sosial yang berupa kepercayaan dapat membantu rumahtangga petani untuk mendapatkan pekerjaan baik usahatani atau non tani. Rumahtangga petani Desa Ciaruteun Ilir saling memberikan kepercayaan untuk pekerjaannya sehingga ketahanan pangan rumahtangga dapat terpenuhi sehari-harinya. Jaringan sosial memudahkan para petani dalam mendistribusikan hasil panen sayuran mereka sehingga pendapatan yang diterima dapat dari berbagai pihak. Saat jaringan yang dimiliki petani banyak maka ketahanan pangan rumahtangga petani akan semakin baik pula. Norma sosial memiliki peran tersendiri dalam menjada ketahanan pangan rumahtangga petani. Norma yang ada dalam kelembagaan petani di Desa Ciaruteun Ilir membantu petani untuk mendapatkan pangan ketika mengalami kesulitan

\section{Daftar Pustaka}

[BPS] Badan Pusat Statistik. 2013. Profil Kemiskinan di Indonesia September 2012. Jakarta (ID): BPS.

Coleman J. 1990. Foundations of Social Theory. Cambridge Mass: Harvard University Press.

Inayah. 2012. Peranan Modal Sosial Dalam Pembangunan. Jurnal Pengembangan Humaniora. 12(1) [Internet]. [Diunduh pada tanggal 15 Maret 2013].

Mustofa. 2012. Analisis Ketahanan Pangan Rumahtangga Miskin dan Modal Sosial di Provinsi Daerah Istimewa Yogya-karta. Jurnal Geomedia. 10(1). [Internet]. [dapat diunduh dari: http://staff.uny.ac.id].

Pemerintah Republik Indonesia. 1996. Undangundang Republik Indonesia Nomor 7 Tahun 1996 tentang Pangan. Jakarta (ID): Sekretariat Negara

Santosa PB. 2013. Tantangan Masalah Pangan. [Internet]. [dapat diunduh dari: http://feb.undip. ac.id].

Sinaga, Rudiyanto. 2012. Peran Modal Sosial dalam Mendorong Sektor Pendidikan dan Pengembangan Wilayah di Kecamatan Garoga Kabupaten Tapanuli Utara. [Internet]. [dapat diunduh dari: http://repository.usu.ac.id].

Singarimbun M. 1989. Metode dan Proses Penelitian. Singarimbun M, Effendi S, editor. 1989. Metode Penelitian Survai. Jakarta (ID): LP3S.

Tim penelitian ketahanan pangan dan kemiskinan dalam konteks demografi Puslit Kependudukan LIPI. 2013. Ketahanan Pangan Rumahtangga di Perdesaan : Konsep dan Ukuran. Jakarta (ID): LIPI. [Internet]. [dapat diunduh dari: http:// directory.umm.ac.id]. 